\title{
Sir Thomas More and the Play of Body
}

John Jowett

\section{(2) OpenEdition \\ Journals}

Electronic version

URL: http://journals.openedition.org/shakespeare/661

DOI: 10.4000/shakespeare.661

ISSN: 2271-6424

\section{Publisher}

Société Française Shakespeare

\section{Printed version}

Date of publication: 1 November 2005

Number of pages: $75-89$

ISBN: 2-9521475-2-3

\section{Electronic reference}

John Jowett, "Sir Thomas More and the Play of Body », Actes des congrès de la Société française Shakespeare [Online], 23 | 2005, Online since 01 January 2007, connection on 19 April 2019. URL http://journals.openedition.org/shakespeare/661; DOI : 10.4000/shakespeare.661 


\section{Shakespeare et le jeu}

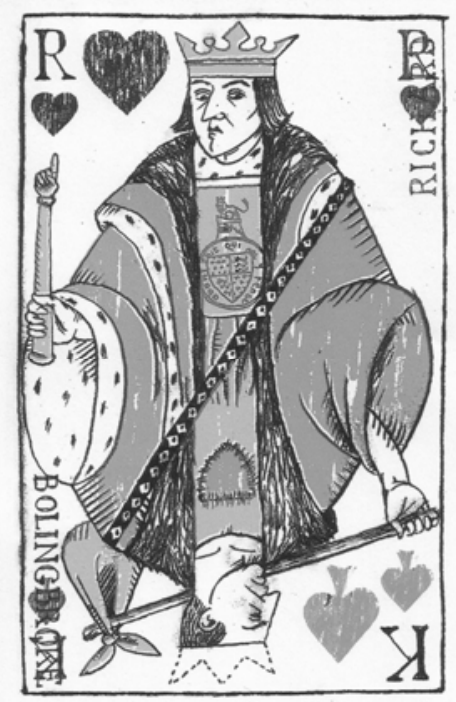

actes du Congrès organisé par la

SOCIÉTÉ FRANÇAISE SHAKESPEARE les 10, 11 et 12 mars 2005

textes réunis par Pierre KAPITANIAK sous la direction de Yves PEYRÉ 


\title{
COMITÉ SCIENTIFIQUE :
}

\author{
Margaret Jones-Davies \\ Gisèle Venet \\ Jean-Marie Maguin \\ Yves Peyré \\ François Laroque \\ Pierre Kapitaniak
}

COUVERTURE :

Edouard Lekston, King and Kusin, 2005

edlek@free.fr

conception graphique et logo

Pierre Kapitaniak

(C) 2005 Société Française Shakespeare

Institut du Monde Anglophone

Université de Paris III - Sorbonne Nouvelle

http://recherche.univ-montp3.fr/SFS/

5 rue de l'École de Médecine

75006 Paris

ISBN 2-9521475-2-3

Tous droits de traduction, de reproduction et d'adaptation réservés pour tous les pays 


\title{
Sir Thomas More and the Play of B Ody
}

\author{
John JOWETT
}

Sir Thomas More is a major dramatic text for its exploration of the idea of playing. Acting, roleplaying, and game-playing are seen as constitutive of More as both politician and private man. The paper will relate these characteristics of the role to the play's word-play on the name 'More' itself. Playing enables More to be more: more witty, wise, humane, successful as a bearer of public office. The one matter that resists joking and playing is the King's demand that More sign the 'articles' of the Act of Supremacy. More now loses public office, but the playing that culminates on the public stage of the scaffold deepens the portrayal of the personal and spiritual man. The playing will be analysed with focus on play with the human body under the main headings of emblematic substitution (the acting of roles of other staged characters) and emblematic metonymy (hair and the beard in relation to the head and the attributes of the mind).

Sir Thomas More est un texte majeur en ce qu'il explore l'idée du jeu. Le jeu d'acteurs, le jeu de rôles et l'activité ludique, apparaissent comme constitutifs du personnage de More à la fois comme homme politique et comme personne privée. Cet article reliera ces caractéristiques du rôle au jeux de mots sur le nom de "More " lui-même. Le jeu permet à More d'avoir quelque chose de plus (more): plus d'esprit, de sagesse, d'humanité, de succès dans l'exercice de sa fonction publique. Le seul aspect qui résiste à la plaisanterie c'est l'exigence du Roi pour que More signe les "articles" du Act of Supremacy. More perd alors sa charge, mais le jeu qui culmine sur la scène publique de l'échafaud approfondit le portrait de l'homme intime et spirituel. Ce jeu sera analysé en accordant une attention particulière eu jeu sur le corps humain sur le mode de la substitution emblématique (le jeu de rôles des autres personnages sur scène) et de la métonymie emblématique (les cheveux et la barbe en relation avec la tête et les attributs de l'esprit).

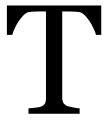

his paper will suggest that the partly Shakespearian play Sir Thomas More uses tropes connected with disguise and alteration of self as aspects of what is referred to in the play as Wit. These contribute to the portrayal of More's character as a man of wit in all its early modern aspects. The play also articulates a series of phantoms, or gestic figures, that represent alternatives to the More that is literally portrayed, assertions of what More is also, might be, or, overtly at least, is not.

A stage character or dramatic role is the most obvious agent and location of the gestic quality of wit, but the play has its own kind of wit in correlating character, theme, structure, and so on, around this very principle of wit. Thus I position "wit" as both theme and co-ordinating metatheme. I broach this matter by asking: How does this drama about a sombre question of religious conscience and politics fabricate space for play and wit? Much of the answer lies in the unpredictable 
conjunction of source materials and the resourceful use of partly anecdotal and partly fictional material about More as a witty man to weld it together. The dramatist Anthony Munday, and any collaborators he may have had, were confronted with a conspicuous gap between the events of the "Ill May Day" as described in Raphael Holinshed's Chronicle which do not greatly involve More ${ }^{1}$ and More's life as related in the pious biography by More's son-in-law William Roper and transmitted in the manuscript accounts of Nicholas Harpsfield. The play was provided with extra episodes of a quasihistorical, anecdotal, or fictitious nature that show More engaging in various kinds of play-acting. Most are placed in between the insurrection episode and the scene showing More's house arrest. In terms of both narrative and theme, they form the vital copula that makes a playful play out of the disparate source materials. ${ }^{2}$

These pivotal scenes are anticipated in Sc. 2, a comic and fictional episode in which the focus switches away from the developing insurrection of Sc. 1 to introduce More for the first time. The Mayor notes that the "weightier businesses" of the session has already been dealt with (107). ${ }^{3}$ More, at this point a sheriff of London, devises what he calls a "merrie iest" (183) in which he connives with the thief Lifter, persuading him to lift Justice Suresby's purse in order to demonstrate that theft falls on those who invite it by negligence. More is simultaneously introduced as a witty character and made instrumental in shifting the tone from weighty business to wit.

\footnotetext{
${ }^{1}$ More's intervention, along with "others", is mentioned briefly in Raphael Holinshed, Henrie the Eight, sonne and successor to Henrie the seuenth (from The Chronicles of England, Scotland and Ireland, London, 1587), online at SCETI (http://dewey.library. upenn.edu/sceti/flash.cfm?CFID=1474580\&CFTOKEN=26731069), p. 842. In Holinshed's account, More did not succeed in persuading the rebels to cease.

${ }^{2}$ Compare Judith D. Spikes's account of the play's structure, in "The Book of Sir Thomas More: Structure and Meaning”, Moreana 43-4 (1974): 25-39. Arthur F. Kinney also stresses the symmetry between the early and later scenes, in "Text, Context, and Authorship of The Booke of Sir Thomas Moore", in Sigrid King, ed., Pilgrimage for Love: Essays in Early Modern Literature in Honor of Josephine A. Roberts (Tempe, AZ: Arizona Center for Medieval and Renaissance Studies, 1999): 133-60.

3 Quotations, line references, and scene numbers from The Book of Sir Thomas More, ed. W. W. Greg (Oxford: Malone Society, 1911), revised edn. with a supplement by Harold Jenkins (1961). Line references are to the Original Text unless specified as to an Additional Passage (eg, 'Add. IV').
} 
The play follows up on the insurrection scenes and leads towards the moment of More's arrest by showing three incidents similar in kind to Sc. 2. These might also be called "merry jests". And it is these that form the copula between the two halves. I will be suggesting that this copula establishes a play structure that echoes the title of the play performed within the play (and indeed within one of the scenes in question), which is called The Marriage of Wit and Wisdom. This internal play title provides us with a vital link between structure and theme, structure and characterization. Ultimately, More himself embodies the marriage of Wit and Wisdom, just as More is the most important common element in the physical, energetic, and often witty insurrection episode and the calmer, more spiritually aware biography of More's arrest and execution. And it is in the copula scenes that the dramatisation of More is consolidated in such a way that the dramatic role can be transported from the first section of the play to the last - consolidated, that is to say, on a conceit, in paradox, in witty playfulness - and so represented as a mobile subjectivity that moves between the poles of wit and wisdom.

The first of the three copula scenes shows More's joke at the expense of Erasmus in dressing his manservant Randall as himself. Though the episode is loosely based on anecdotes about Erasmus' failure to recognise More on their first meeting, ${ }^{4}$ the role of Randall is fictitious. The simulacrum of Randall dressed as More accompanies the real office-holder on his first appearance with the accoutrements of office. The stage direction in the Original Text reads:

A table beeing couered with a greene Carpet, a state Cushion on it, and the Pursse and Mace lying thereon...

(735-6)

This insistent and ostentatious presentation of the symbols of office leads to the entry of what an audience would first see as apparently two Lord Chancellors:

Enter Sir Thomas Moore and his man Randall with him, attyred like him.

\footnotetext{
${ }^{4}$ See Vittorio Gabrieli and Giorgio Melchiori, 'Additional Note to III.i.184-5', in their Revels edn. (Manchester and New York: Manchester University Press, 1990), 208-9.
} 
This is clearly a comic piece of staging, even before More speaks, and perhaps for the anticipated audience a momentarily disorienting one too.

In the initial exchange between Randall and More, wordplay on clothing develops the idea of role-playing: Randall says that "I stand but vppon a fewe pointes" (739) and that he has "learnde your shift so well" (757). Points were also the laces that attached breeches to hose. The word shift here is a neat reminder of More's newly elevated status, punning on the senses (a) device, trick; (b) set of clothes; (c) "Change or substitution of one thing for another of the same kind" $(O E D, 7)$. As if emerging from this wordplay on shift, the game-play with Erasmus will test out whether, if Randall can "act my parte" (748) and "dress thy behauiour / according to my cariage", true "merit" can be distinguished from mere "outward ceremonie" (751-3). Like "act my part", the phrase "dress thy behauiour / according to my cariage" is theatrical, as though More as a professional actor were training the journeyman, and Randall responds with this understanding when he says "if I doo it not in kew, let your Lordship bannishe me from wearing of a golde chaine for euer" (762-3), or, in the revised text, "If I doe not deserve a share for playing of $\mathrm{yo}^{\mathrm{r}} \mathrm{Lo}$. well. lett me be yeoman vsher to $\mathrm{yo}^{\mathrm{r}}$ Sumpter and be banisht from wearing of a gold chaine for ever" (Add. IV.21-2). This speech tellingly conflates the idea of the share-holding actor and the office holder. In both versions More responds "set thy countenaunce, act thy parte / with a firme boldnesse, and thou winnest my hart" (7645), language that is theatrical at every point.

In the event, Randall turns out to be a very poor actor, and Erasmus sees through the disguise without much difficulty. The roleplaying breaks down when Erasmus addresses the supposed More in a short Latin speech, which to Randall is incomprehensible.

The second incident, like those involving Lifter and Randall, shows More dealing with a figure of low social status: like Randall, the long-haired ruffian Falkner is a servingman, and like Lifter, he is brought before More on a charge of criminal behaviour. Falkner's pretence to wear long hair "vppon a vow" (799), raises a question that no observant reader can fail to ask about the play as a whole: what is 
the significance of its repeated and sometimes almost obsessive references to hair?5 These details about hair begin more or less subliminally in the identification of the strangers as "Lombard(s)" (41; Add. II.82 and 104; also Tilney's alteration from "straunger" and "ffrencheman" at Original Text 364 and 368), which meant "longbeards". The most prominent amongst them happens to be named as "de Bard" (named in dialogue at 54, 332, 340, and 420), which highlights both his Lombard identity and the presumed beardedness of Lombards. The interest in hair leads through Falkner's long hair, then the missing property of the stage beard for Wit in the staged play The Marriage of Wit and Wisdom (both of which I will consider in more detail shortly), and so to the disquisitions on More's beard in the later scenes.

In the Falkner episode it becomes clear that hair and authority are related matters. The scene does not relate to any episode in the sources dealing with More, but instead comes from an incident recorded in Foxe's Acts and Monuments of Martyrs in which the figure equivalent to More is Sir Thomas Cromwell, More's political enemy who replaced him as Henry viII's chief advisor and served as his main agent in the dissolution of the monasteries. ${ }^{6}$ Is this an innocent transposition from Cromwell to More purely for the sake of the anecdote itself and its contribution to the theme of hair? As some of the comments that follow might affirm from a different angle, there would seem also to be provocative overtones of religious politics.

Long hair is presented in the Falkner episode as a defiance of authority; it gives visual stage representation to Falkner's identity as a "ruffian". Objections to long hair as unfitting for a man were grounded in Ezekiel 44:20, "They shall not also shaue their heades, nor suffer their lockes to growe long", and 1 Corinthians 11:14, "Doeth not nature it selfe teach you, that if a man haue long heare, it is a shame vnto

\footnotetext{
5 As noted in Charles Clay Doyle, "The Hair and Beard of Thomas More (with Special Reference to the Play Sir Thomas More and an Epigram by John Owen)", Moreana 71-2 (1981): 5-14. See also Giorgio Melchiori, "The Contextualization of Source Materials: The Play within the Play in Sir Thomas More", Le forme del teatro 3 (1984): 59-94.

${ }^{6}$ Vittorio Gabrieli, "Sir Thom as More: Sources, Characters, Ideas", Moreana 90 (1986): 1743 (18-19).
} 
him?". 7 Long hair represents a challenge to authority and in the period was repeatedly the hallmark of the "ruffian" (in the stage direction and Add. IV.25, and in dialogue at 797, 862, and Add. IV.33, 63, and 64). Yet Falkner presents this challenge on the basis of a vow. Is this a regretted religious vow or a tavern oath? More's game is to distance Falkner's oath from associations with ruffianly behaviour. He disingenuously declares that "vowes are holy things, if they be made / to good intent" (806-7), or, in the revised text, "vowes are recorded in the court of heaven. / for they are holly acts" (Add. IV.79-80). On Falkner's behalf, yet in jest, More postulates that there is a serious conflict here between obedience to God and obedience to the state.

The play-acting in Sir Thomas More creates repeated frissons relating to the serious aspects of More's own identity and fortune. As Randall enacts More, in the Marriage of Wit and Wisdom scene More does no more than enact an aspect of himself when he takes on the role of Good Counsel. The Erasmus scene in particular trains the audience to read these episodic incidents as gestic emblems rather than for their contribution to a linear narrative, so that when we come to the Falkner episode we are already attuned to seeing the play's most serious matter acted out playfully.

My point is that More playfully constructs a mock crisis for Falkner that foreshadows his own unplayful dilemma when he is required to sign the articles. It has often been noticed that the play is cautiously evasive in its treatment of this key moment, More's refusal to assent to the Act of Supremacy that set Henry viII at the head of the Church of England. Henry appears nowhere in the play, and the content of the articles falls under a conspicuous erasure. The censorship of the insurrection scenes that is so literally and destructively inflicted on the manuscript is palpable present here too, casting an oblique shadow on the text. The dramatists evidently avoided being explicit in an attempt to prevent censorship when the play came before Tilney. And so it entirely makes sense that the evasion in presenting the matter of the Act of Supremacy should result in displaced and comic eruptions of the key issue elsewhere.

\footnotetext{
${ }^{7}$ Quoted from the Geneva Bible (1587).
} 
Having constructed Falkner's dilemma as one of divided allegiance between God and state, More resolves it by insisting that Falkner should follow his conscience even if that means suffering secular punishment:

and Sir, you shall not say, you were compelde by me to breake your vowe.

But till the expiration of the same, because I will not haue ye walke the streetes, for euery man to stand and wunder at, I will cõmitt ye prisoner vnto Newgate. Except meane time, your conscience giue you leaue, to dispense with the long vow that you haue made Away with him.

(807-15)

He prescribes to himself similarly later in the play: he acts on his conscience and suffers the consequences willingly.

The Falkner scene thus anticipates his later course through play. The nature of the play is particularly clear in an exchange that is exclusive to the Original Text in Munday's hand, in which Shrewsbury and Surrey are present during the initial exchange:

Faulk. My Lord, I weare my haire vppon a vow.

Shrew. But for no penaunce of your sinnes I feare.

Sur. No, hees no haire-cloth man, though he weare haire.

(799-801)

And when More sends Falkner to prison Surrey comments, "A Cell moste meete for such a votarie" (816) - playing on the "cell" as place of imprisonment and hermit's recluse, a votary being, of course, one who is bound by vows to a religious life. The terms of reference are specifically Catholic. A man with long hair might be a hermit. He might even be one of those disorderly plebeian prophets who deliver disturbing and antiauthoritarian messages to those in authority, such as Peter of Pomfret in Shakespeare's King John. Such a figure would belong to the medieval Catholic world, or appear as a remnant of it in a more recent time. Such a figure might indeed grow his hair as an outward sign of his religious commitment. But, being as it is that Falkner is not a religious hermit, and that More is not Falkner, More does nevertheless have his own crucial affinities with the projected 
figure of the Catholic, the penitent, and the man who suffers at the hands of secular authority for his faith.

One detail in particular helps to secure this association. Unlike Falkner, More was a penitent specifically in that he did wear a haircloth. Harpsfield relates that More wore a hair shirt, and notes elsewhere that he sent it to his daughter Margaret Roper the day before his execution. ${ }^{8}$ The shirt so became a relic of the Catholic martyr after his death.

More in this episode is himself, he is Cromwell read through the Protestant polemicist in Holinshed, as the effective restrainer of decadence, and he is also Falkner, in his fantasised capacity as the religious man whose holy vow leads him to be punished by the secular authority. Such is the ambiguity of role-playing-a point definitively established for us in the episode of Randall's impersonation. More can occupy the position of both authority figure and its other, in this case the figure who represents the resistance to authority. Symbolically speaking, More will always be both hairy and clean cut - a point to which the play returns in the closing scenes.

To leave the matter there would be to overlook an aspect of Falkner's haircut that is crucial to the ludic quality of the hair-play. An offstage haircut is unlikely to involve the irrevocable cutting of actual hair. Instead, Falkner's "lothsome excrement" (852) is likely to have been staged with the actor wearing a wig, which indeed was established normal playing practice for long hair, as in the regular example of the boy actor playing a woman. The point would scarcely be worth making, were it not that it establishes a strong line of connection between the haircut episode and the scene that immediately follows it in both versions: the scene in which More participates in the players' production of The Marriage of Wit and Wisdom. If we think of this scene as offering a commentary on the Falkner episode, it does so by making manifest the theatrical foundations of removable hair, most overtly in the stage direction "Enter Luggins with the bearde" (1135).

\footnotetext{
8 Nicholas Harpsfield, The life and death of $S^{r}$ Thomas Moore, knight, sometymes Lord high Chancellor of England, ed. R. W. Chambers (London, New York, and Toronto: Oxford University Press, for the Early English Text Society, 1932), 65 and 200.
} 
This, the third incident in the jestbook-like middle section of the play, finally and unequivocally puts More himself in the role of actor. ${ }^{9}$ That is, he stands in for and so impersonates the missing actor Luggins by playing the role of Good Counsel. Here again, in More's participation in the interlude there is obvious interplay between the impersonator and the impersonated, directed at developing our sense of More's subjectivity. On the one hand, Luggins, the actor whom he replaces, is another of those plebeian figures with whom More is keen to interact, like Lifter, Randall and Falkner. We repeatedly sense More's social anxiety in dealing with the Lord Mayor and his other guests at the banquet, as when he reproves his wife for leaving the guests unattended, but he seems very much at ease in dealing with the actors. As for Good Counsel, the role he enacts, I have already pointed out that he represents one aspect of More himself. Moreover the titular theme of the play performed by the actors, The Marriage of Wit and Wisdom, clearly announces that More himself is the embodiment of such a marriage. As the actual main source of the interlude performed in the play is Lusty Juventus, the alteration of the title to The Marriage of Wit and Wisdom is effected precisely to serve the thematic purpose.

The wit is More in his ludic role, the role-player and the jester. In other words, More's play-acting displays his own wit, even as he acts with an actor playing a role called Wit, and simultaneously asserts him to be Good Counsel, who guides Wit towards Lady Wisdom. What is unusual about the interlude as acted in Sir Thomas More is precisely the absurd requirement for a beard. This is a surprising property for the role of young Wit. Beards were associated with age and, sometimes, wisdom. And indeed, a transformation from a bare chin to a beard would be unusual in a play. Yet in Sir Thomas More the property seems so important that the players almost wreck their play in their determination to get hold of a beard for young Wit to wear. The actor

\footnotetext{
${ }^{9}$ The fictional scene is loosely based on Harpsfield's account that More, when a page in Cardinal Morton's household, 'among many other tokens of his quicke and pregnant witt, being very yonge, would yet nothwistanding vpon the [soden] stepp in among the Christmas players, and forthwith, without any other forethinking or premeditation, playe a part with them himselfe, so fitly, so plausibly and so pleasantly, that the Auditours tooke muche admiration, and more comfort and pleasure thereof then of all the players besydes; and especially the Cardinall, vpon whose table he wayted' (10-11).
} 
called Luggins is sent off in a hurry to the beard-maker Ogle's, ${ }^{10}$ but meanwhile, at More's urging, the play begins without Luggins.

It is therefore the absence of a beard for the enacted play that makes More's intervention necessary. Curiously, a point is made about More's own beard being inadequate for the role: when he explains the delay to the Lord Mayor he adds, "Ide lend him mine, but that it is too thinne" (1026). The joke about the thin beard may or may not be designed as another metatheatrical touch, on the assumption that the actor playing More would need to wear a thin beard as a stage property. A stage-property beard can indeed theoretically be lent.

Wit's beard is presented as both a symbol of wisdom and a material object. More refers to Wit as being without "the commoditie of a bearde" (1055), with commodity meaning both "asset, advantage" and "object, article". It is the commodity in the second sense that is manifested when the exhausted actor Luggins returns too late from his shopping trip, now finally beard in hand, though not beard on face. Time has run out, the banquet is ready, and the play proceeds no further. What I have called the jestbook episodes are as a whole coming to a close, and the beard, having finally made its appearance in Luggins's hand, never makes it to young Wit's face, remaining a token of a dramatic potential that is never realised.

From the next scene the play resumes the historical account of More. The scene unfolds in what More calls the "serious square" of the Council chamber (1176), and in the same speech More refers to the Council's heavy responsibility for "the health and preseruation of the land" which involves a mix of applying "choise diett" and "letting blood" (1178-80). And this is the very scene in which Palmer brings those unspecified articles for the Council to sign, and places More under house arrest when he refuses to do so. With the dismissal of the players the play takes a decisive turn towards More's death, with the words "serious square" operating as a genre signal in much the same way as "merry jest" in the Lifter scene.

\footnotetext{
${ }^{10}$ The Ogle family supplied the theatre with wigs and other properties between 1571 and 1600 at least: E. K. Chambers, William Shakespeare: A Study of Facts and Problems, 2 vols. (Oxford: O.U.P., 1930): 1:510. The reference to this actual person is an anachronism that relates the scene to the Elizabethan present.
} 
But the play has not finished playing with hair. When More greets his wife and family in Sc. 11 he says:

wife, giue me kinde welcome, thou wast wunt to blame my kissing, when my beard, was in the stubble,

But, I haue bin trimde of late, I haue had, a smoothe Courte shauing, in good faith I haue...

Are we to suppose that More's thin beard has now actually been shaved off? Whether this is a purely allegorical court shaving or reflects a fact about his appearance is uncertain, but facial hair is still an issue, and indeed More's joke about his beard is the very first manifestation of the survival of his whimsical humour in the face of his impending execution.

If we read the "a smoothe Courte shauing" literally we run into a double inconsistency that heightens the questions of how More will appear on stage and when if at all he has that shave. If, as we have seen, in Sc. 11 More claims to have had a smooth court shaving, in Sc. 16 he determines not to shave before his execution. But in Sc. 17, the last, he attests, as in Sc. 11, that he has been shaved: "One thing more, take heed thou cutst not off my beard: Oh, I forgot, execution past vppon that last night, and the bodie of it lies buried in the Tower" (1954-5). This line oddly invokes Holinshed's account in which, "euen when he should laie downe his head on the blocke, he hauing a great graie beard, stroked out his beard, and said to the hangman, I praie you let me laie my beard ouer the blocke, least you should cut it", with the comment, "Thus with a mocke he ended his life"." Even as the anecdote is remembered, it is replaced by the contradictory narrative that More has been shaved. This adds to the difficulties in staging the story of More's beard with consistency, though it is scarcely to be entertained that on stage More's beard was supposed to be present then removed then present then removed again.

We here confront a glaring inconsistency in the meaning of hair and beards that seems to be played out in the contradictory statements about the fate of More's beard. On the one hand, long hair is ruffianly, and a long beard too might be a sign of social and moral irregularity. In

\footnotetext{
${ }^{11}$ Holinshed, Henrie the Eight, 938.
} 
words appended to a chapter in Cresacre More's Life and Death of Sir Thom as More and probably written by the Catholic apologist Richard Rowlands, More displayed "A chinne of Temperance closely shaued / From care of wordlie pelfe". ${ }^{12}$ This, of course, is how we remember More ourselves, from the portraits of Hans Holbein. The "chinne of temperance" conflicts with the beard associated, through The Marriage of Wit and Wisdom, with maturity and perhaps indeed wisdom itself. But it is this rather than Holinshed's great grey beard that the dramatist chose to represent as the final say on More's chin, presumably for the sake of the symbolic meaning marked out Rowlands.

It seems to me that this sort of played-out contradiction between the connotations of hair and beard works in much the same way as the ludic principle itself: acting, and specifically the putting on of stage properties such as wigs and beards, allows the actor to assume different and logically inconsistent roles, a principle that is extended both physically and symbolically to More himself. I would suggest, moreover, that the inconsistency arises most clearly in the scene that brings acting most obviously to the fore, the scene in which More participates in The Marriage of Wit and Wisdom. Here it is the beard of wisdom that is presented, not the long hair of the ruffian. The beard for young Wit represents an attribute of More's character distanced from More's body. It is also detached from its supposed wearer Wit. And it is alienated from its referent Wisdom, who is both female and absent from stage.

This context both enables and qualifies the prominent treatment of the idea of More as a spiritual being in the closing passages. More will lose his beard by losing his head, and so his life. More's meditations on facing the prospect of death are made up of grimly amused anatomisations of parts of the body and items of clothing that cover it. By this stage in the play, these are firmly established as the attributes of the actor. They are now presented equally as the mortal aspect of More as a human being. Divestment of garments becomes a Christian metaphor for relinquishing the mortal

\footnotetext{
12 STC 18066. Quoted in Doyle, "The Hair and Beard": 9.
} 
body. But so too does divestment of hair. More's correlation of the barber who would remove his beard with the headsman who will remove his head affirms a combination of metonymy and metaphor as the principle that has underlain the references to clothes and hair: metonymy in that the beard, for instance, stands for the head and the head in turn stands for the body itself (hence "the headsman now shall cut off head and all", 1128); metaphor in that these physical elements are figurations of the condition of mortal life.

The symbolic narrative I have been tracing moves from the divestment of clothes to the removal of hair to decapitation. The human body becomes subject to conceits of vestment, alteration, supplementation, divestment, reduction, and even dismemberment. There is an overarching progress from wit to wisdom. Christian stoicism says that life is a brief episode, that the body is lent from God, that life is likely to involve suffering, and that death is a release from the physical confines of this earth. This is the view left when More finally renounces wit itself:

we goe to sigh, that ore, to sleepe in rest.

Heere Moore forsakes all mirthe, good reason why, the foole of fleshe must with her fraile life dye.

No eye salute my trunck with a sad teare,

Our birthe to heauen should be thus: voide of feare.

$(1978-82)$

Wit, here "mirthe", is forsaken insofar as it is the mere "foole of fleshe"; this aspect of wit, at least, belongs to the mortal body of the "fleshe" or "truncke", and so "must with her fraile life dye". In this formulation the soul as it passes through death is subjected to a curious negation of selfhood; it is "voide of feare" but also void of mirth, void of body, void of More: to quote More's words a few lines earlier, he is "loathe to take more".

A play such as this is in itself a kind of conceit, or an emblem of Wit. Wit will gain a long beard and a wife, though this does not actually happen in the play as we see it; the mortal man of wit will progress to the state of states, but only at the cost of abandoning wit itself. Wit and Wisdom correlate with body and soul. It seems significant, then, that the play makes repeated wordplay on More's very name as an adjective or adverb denoting the supplement or excess that is denoted by the 
word "and" itself. The joke on More's name is, of course, in itself an example of wit, of supplementary meaning, whereby the word "More" becomes more than the name "More".

But the other, material, supplementation associated with Wit is all too vulnerable in ways some of which can be and are represented metatheatrically: fortune can and perhaps characteristically will be reversed, and a beard or a long head of hair or even the physical organ of the head can all too easily fall prey to the razor, the knife, or the axe.

We have seen that More's hairshirt became a precious relic. According to Aubrey, so too did More's head:13

His head was upon London Bridge: there goes this story in his family, viz that one day as one of his daughters was passing under the bridge, looking on her father's head, said she, "That head has lain many a time in my lap, would to God it would fall into my lap as I pass under." She had her wish, and it did fall into her lap, and is now preserved in a vault in the cathedral church at Canterbury. The descendant of Sir Thomas More, is Mr More, of Chilston, in Hertfordshire, where, among a great many things of value plundered by the soldiers (in the Civil War) was his chap, which they kept for a relic. Methinks 'tis strange that all this time he is not canonised, for he merited highly of the Church.

The play shows a different process of remembering, in which the performative quality of wit is essential. I am struck by the complex poetic texture of this and other early modern history plays as acts of remembering, or re-membering. With reference to Sir Thom as More I would put it this way: drama is no miracle, because it depends on declared illusion: the illusion, to be precise, of one body taking on a wittily augmented existence as a representation of another body. The comic property of the long beard is emblematic, then, of acting in general, like the actor's put-on deformity in a performance of Richard III. And so: the beard is emblematic of this particular play's project of remembering Sir Thomas More by presenting the actor's bodily imitation of him before the eyes of the theatre audience, up to, but not including, the moment where he is made void of life by the cutting of his head. Thus the play's martyrological theme can be

\footnotetext{
13 John Aubrey, Brief Lives, ed. Richard Barber (London: Folio Society, 1975), 221. I am grateful to Tiffany Stern for pointing this out to me.
} 
articulated only insofar as it is both disguised and deconstructed by the metatheme of acting.

JOHN JOWETT

Shakespeare Institute 